This item was submitted to Loughborough's Research Repository by the author.

Items in Figshare are protected by copyright, with all rights reserved, unless otherwise indicated.

\title{
Fifteen pupils' positive approach to primary school science: when does it
} decline?

PLEASE CITE THE PUBLISHED VERSION

http://dx.doi.org/10.1080/03055690903148662

PUBLISHER

(c) Taylor and Francis

VERSION

AM (Accepted Manuscript)

LICENCE

CC BY-NC-ND 4.0

\section{REPOSITORY RECORD}

Turner, Sarah, and Gren Ireson. 2019. "Fifteen Pupils' Positive Approach to Primary School Science: When Does It Decline?". figshare. https://hdl.handle.net/2134/10246. 
This item was submitted to Loughborough's Institutional Repository (https://dspace.lboro.ac.uk/) by the author and is made available under the following Creative Commons Licence conditions.

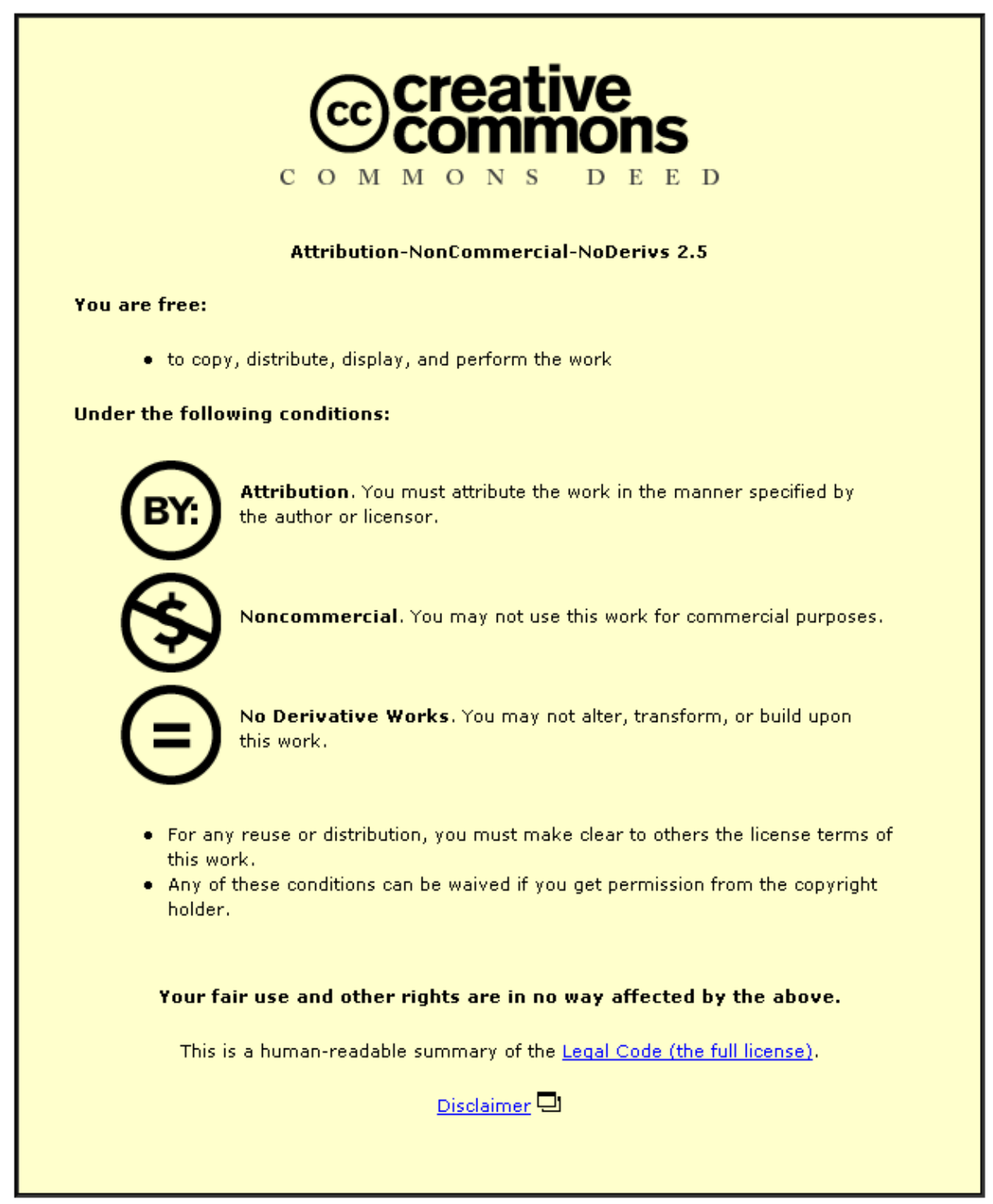

For the full text of this licence, please go to: http://creativecommons.org/licenses/by-nc-nd/2.5/ 


\section{Pupils' positive approach to primary school science: when does it decline?}

Sarah Turner ${ }^{\mathrm{a}}$ \& Gren Ireson ${ }^{\mathrm{b}}$

\section{SUMMARY}

The decline in secondary school pupils' attitudes towards science is well documented (Choppin, 1974; Hadden and Johnstone, 1983; Simpson and Oliver, 1985; Hofstein et al., 1990). However, recent research has shown that pupils' attitudes to science appear to become fixed during their primary school years (Turner, 2008). This study investigated end of Key Stage 1 (Yr 2 (ages 6-7yrs)) and end of Key Stage 2 (Yr 6 (ages 10-11yrs)) pupils' attitudes to science, using Klopfer's themes (1971), through a paired activity and interview for $\mathrm{Yr} 2$ pupils and a pre and post Test Of Science Related Attitudes (TOSRA) (Ledbetter and Nix, 2002, adapted Fraser, 1981) questionnaire (adapted) for Yr 6 pupils. The questionnaire was analysed using the mean and chi square values and Cronbach alpha was calculated to test reliability. The results revealed that while Yr 2 pupils exhibit a thirst for knowledge and enthusiasm for science, Yr 6 pupils' attitudes over the period of one academic year did not change: their attitude toward science was fixed. This insight raises some implications and responsibilities for primary school teachers.

Keywords: attitude; science; primary education.

\footnotetext{
${ }^{a}$ Loughborough University, England. Corresponding author: email: S.Turner4@lboro.ac.uk

${ }^{\mathrm{b}}$ Nottingham Trent University, England
} 


\section{Introduction}

For many pupils an interest in science emerges from a young age and it is the primary school teacher who will make a valuable contribution in laying the basic foundations of knowledge and encouraging pupils to be inquisitive, to experiment and to discover for themselves (Dowling, 2001). As pupils commence primary school, many display enthusiasm for science even though it is perceived as difficult (Pell and Jarvis, 2001).

However, during primary school this initial enthusiasm declines and Murphy and Beggs (2003) summarise some reasons for this trend:

- The nature of the scientific content of the curriculum;

- Science teaching being ineffective;

- The perception of school science as being difficult;

- Parental/social factors.

Over the last 50 years, primary school science has been transformed (Jenkins, 2004) and this could be a key factor for the decline in pupils' positive attitudes. While there are statutory requirements for scientific content stated in the National Curriculum in England and Wales (1989), teachers will interpret some aspects differently, teaching topics from varying perspectives that relate to their own experience and expertise. Depending on the school and the facilities and equipment available, some pupils will have experienced little or no practical work during their primary years (Braund and Driver, 2002). The National Curriculum should prepare pupils for their study of science during all of their schooling and beyond: 
'School science is a reflection of science in the 'real' world, where scientists learn from each other and extend the boundaries of knowledge by research' (National Curriculum Council, 1989, p. 5).

\footnotetext{
'Through science, pupils understand how major scientific ideas contribute to technological change - impacting on industry, business and medicine and improving quality of life. Pupils recognise the cultural significance of science and trace its worldwide development. They learn to question and discuss sciencebased issues that may affect their own lives, the direction of society and the future of the world.' (QCA, 1999, p. 15)
}

The success of this aim will depend on both the teacher and the school. The knowledge and interest of the teacher, in science, will affect how much science is related to everyday life. Within the constraints of a timetable and available facilities these factors could hinder the ability of pupils to experiment freely.

Changes to primary teaching were introduced by the National Literacy and National Numeracy Strategies (1998 and 1999 respectively). As a result science was commonly timetabled during afternoon teaching sessions (Murphy and Beggs, 2003) when pupils are more tired and concentration spans reduced. Also, Jarvis (1991) states that science is a subject requiring time if pupils are permitted to perform a practical, discuss results and report their findings. These new strategies may have had a negative impact on the teaching of, and pupils' experiences of, science. Recent news reports focus on the unbalanced primary curriculum, which is heavily dominated with 
numeracy and literacy (Ward, 2009) highlighting this as a one of the reasons why the primary curriculum is under review.

With limited time for experiments and science generally, choice of delivery of science by teachers could result in ineffective science teaching. Within the classroom, pupils enjoy the aspect of 'play' and 'learning through doing'. This can be an advantage in science teaching for example using equipment such as mirrors or magnets (Jarvis, 1991). However, pupils often prefer activities such as painting and home corner play but dislike to engage in writing, mathematics and science (Pollard et al., 1994). Pollard's study also reported that pupils liked curriculum subjects if they found them interesting and fun, and if lessons possessed activities requiring autonomous working. Pupils have reported liking 'science experiments' more than liking 'science' (West et al., 1997). Science can be recognised as a more demanding subject than others, however, as pupils get older, they consider science to be less difficult and this has an impact on their enthusiasm:

'...as the subject is perceived to be easier, enthusiasm for science declines' (Pell and Jarvis, 2001, p. 857).

This is not the expected trend and highlights the importance of the element of challenge that some pupils enjoy about science. Older pupils' perception of science as being less challenging might reflect repetition of key topics and concepts, or how well new components of topics are introduced and carried forward. 
There has been less research regarding primary school pupils' attitudes, perhaps due to the difficulty of using questionnaires (West et al., 1997) or the perceived difficulties associated with young children and interviewing. Piburn and Baker (1993) report that in the results of the National Assessment, the most positive attitudes towards science were held by nine year olds (1977, 1982 and 1986). Recent research at secondary schools reports that young people have made their decision not to follow a career in science by the time they choose their General Certificate in Science Education subjects (GCSEs), implying that it is vital for primary teaching to be of a good standard (Jenkins and Nelson, 2005; Lyons, 2006; Barmby et al., 2008). The action points suggested to address secondary pupils' antipathy toward science, may also be applied to primary, as outlined in the research by Jenkins and Nelson and Barmby et al. Among the crucial factors identified are the importance for an enthusiastic teacher and relevance of a topic to everyday life.

Pupils' experiences and environments can also have an impact on a pupil's attitude. This could be related to family beliefs and attitudes (Osborne et al., 1998) or a pupil's peers (Breakwell and Beardsell, 1992).

The questions to be addressed in this study were:

1 How do pupils feel about the activities undertaken in school science lessons? 
2 When do pupils' attitudes towards science tend to be fixed and what affects it?

3 Are there some of Klopfer's themes that are positive and others negative in each age group?

\section{Methodology}

This practitioner-based study used a pupil paired task and group interview to triangulate the findings of the $\mathrm{Yr} 2$ activity $(\mathrm{N}=44)$ and questionnaires and observations were carried out for $\mathrm{Yr} 6$ pupils ( $\mathrm{N}=106$ pre; 100 post). The questionnaires and paired task were based on Klopfer's themes (1971) (Table I).

Two primary schools participated in the Yr 6 questionnaires (independent $=$ school $A$ and state $=$ school $D$ ) and six schools (ranging from independent/state/special needs) were involved in the $\mathrm{Yr} 2$ paired activity. This longitudinal study, of an opportunity sample, was used with some caution since variation may occur with the sample of pupils chosen (Cohen and Manion, 1980).

\section{Yr 2 Study}

Initially a Pilot Study was undertaken with a small group of eight pupils (four girls; four boys) and wording of questions modified and additional responses added for the main investigation. From speaking to primary teachers a wordcard activity for each question in Klopfer's theme was created, using pictures 
and words. The pupils had to choose their response from a selection of faces describing how they might feel (happy/sad/unsure) (Figure 1).

This method was preferred as it was felt that using a questionnaire was unsuitable for this age group due to the difficulty of reading and writing. Research by Mortimore et al. (1988) used a five point, smiley face scale for $\mathrm{Yr}$ 3 pupils investigating children's attitudes to different aspects of school life and this type of method was deemed suitable for this activity. However, since $\mathrm{Yr} 2$ pupils were being used, only three different faces were used due to the responses either agreeing or not to the suggestion and there was a concern that too many face choices would increase the level of difficulty of the task.

The questions that were asked (and the responses the pupils had to choose from), based on Klopfer's themes, were:

1 Which jobs do you think need you to have some knowledge of science for you to be able to do them? (dentist, policeman, nurse, doctor, fireman, banker, lawyer, typist, paramedic, florist)

2 What do you think Scientists are like as people? (quiet, likes to read, wears a white coat, grey hair, plays sports, watches TV, has a beard, wears glasses, smiles a lot, married and has children, pets at home)

3 What things do you think you need to do in a science lesson to be like a scientist? (find out by myself, repeat an experiment, asking questions, ask the teacher, reading books, try a new experiment, work with friends, go on the Internet, watch videos, ask a friend) 
$4 \quad$ Which of the following everyday objects do you think were

made/developed by scientists? (schools, books, houses, soap, shoes, toaster, computers, cars, medicines, washing machine, aeroplanes, mobile phones)

\section{Which of the following activities do you enjoy in science lessons?} (writing up experiments, watch videos, visit museums, computers, writing stories, drawing diagrams, group work, poster, making things, discussion, writing poems, experiments)

\section{Which of the following activities do you do after school? (play $x$} box games, drawing/colouring, sports, computer games, play with friends, watch television, play musical instrument)

7 What do you want to be when you grow-up? (vet, paramedic, actor, policeman, air pilot/air hostess, doctor, builder, taxi/bus driver, banker, fireman, chef, gardener, school teacher, nurse, lawyer, dentist, florist, musician, typist, mechanic, hair dresser, journalist)

The questions were read out to the pupils and in their pair, they had to agree an option, and if they could not agree, they had to select the 'unsure' option. Participants were $57 \%$ girls and $43 \%$ boys. Choice of the pairs was down to teacher discretion and tended to be mixed ability. During the research I was aware that some of the pupils may not understand the term 'science' and therefore be either apprehensive or unclear with their responses. However, the class teachers did try and illustrate what science means before the activity using examples of topics they had studied that year, however, there was still an uncertainty for some pupils. 
Interviews were used afterwards to probe deeper into the results and to triangulate the word-card activity findings; they are advantageous when complex ideas are involved (Moser and Kalton, 1977) and more in-depth specific questions need to be asked. However, the number of interviews undertaken was limited due to them being time-consuming exercises (Drever, 1997).These were semi-structured which took place with six $\mathrm{Yr} 2$ pupils from school A.

\section{Yr 6 Study}

A pre and post Test Of Science Related Attitudes (TOSRA) (Ledbetter and Nix, 2002, adapted Fraser, 1981) was used for $\operatorname{Yr} 6$ pupils. Initially the Ledbetter and Nix (2002) questionnaire was used as a Pilot Study (see Appendix 1 questionnaire) using only pupils from school A. For the main study (which this report largely focuses on), the questionnaire was modified to improve language and clarity (questions were rewritten to be in the positive form) (Pell and Jarvis, 2001) but also to acquire further information regarding what pupils like at school and how science enjoyment compares to other subjects (see Appendix 2 questionnaire). The responses were ranked using a Likert Scale (strongly agree scored five - strongly disagree scored one); these have been used widely in research and therefore can be used with confidence (Oppenheim, 1992). Questionnaires are a useful research tool as they enable a large quantity of general information to be collected. However, one major limitation reflects on how the researcher interprets the responses given. For the final study, Cronbach alpha score was obtained using Statistical Package 
for Social Sciences (SPSS 14.0) which compared all combinations of the data. A score higher than 0.70 is considered reliable (Nunnaly, 1978). The score for schools $A$ and $D$ was 0.81 . The scores are considered highly reliable (Cohen et al., 2007).

Classroom observations were also undertaken to observe pupil behaviour and their responses to different activities; this enabled the researcher to develop a deeper understanding of how Key Stage 2 science was taught. However, some caution was taken since teachers or pupils may respond differently having an observer within the classroom.

\section{Results: Yr 2}

The results from the Yr 2 activity show that already pupils have a good knowledge of scientists and what they do. (see Table II). They recognised many jobs which were correctly associated with science and the one anomalous result the teacher explained (the typist) was simply because the typist at the school typed up the science notes. There were some jobs, for example lawyers, that pupils were unsure of where to place (see Figure 2).

The perhaps 'stereotypical' view of a scientist with grey hair, a beard and glasses was not completely known by the pupils and there were numerous discussions about these factors and how they would depend on the scientist's age for example. This caused much discussion between the pupils and showed that there is a change in the pupils' thinking about what scientists are like and awareness that all people are different. 
The results regarding 'being like scientists' in a lesson was most encouraging and pupils have clearly been told why and what they are doing experimentally. One articulate pupil expressed a view that the television would not give up-to-date information for scientists to use and that the Internet and experiments would be more useful (see Figure 3). Pupils were keen to be like scientists and to repeat experiments and many wanted to learn new skills through practicals.

Pupils found they did not fully understand what scientists would make or develop, only that they were very clever so complicated things like computers must be made by scientists. This was a difficult question for the pupils and I felt many did not fully understand it. However, it did allow discussions between pupils and they were thinking about why something could be made by scientists or not. This demonstrated that pupils were confused between science, technology and engineering.

Science lessons were very popular and pupils were very enthusiastic. There were many activities within lessons that pupils clearly enjoyed and looked forward to doing. However, some pupils did not like discussions or writing poems (see Figure 4) and these may be viewed more as literacy tasks than science.

The pupils occupy themselves in a variety of after school activities. It is difficult to state whether they were seen as pursuing an interest in science or 
simply an activity they enjoyed. Variety ranged from Brownies/Beavers to playing computer games or with their friends. Some pupils have considered their future career, but the majority were clearly uncertain. The only scientific job they may consider would be veterinary.

In conclusion, the majority of $\mathrm{Yr} 2$ pupils enjoy science lessons and have a good general understanding of what scientists do and how to be like a scientist. But how do they acquire this knowledge at such a young age? A group discussion/interview was used to triangulate the findings of the wordcard activity and also to gain further knowledge of how the pupils derived their responses. The following key points were made:

- Knowledge gained through reading books, going to visit the doctor/dentist, watching television or from their parents' jobs.

- How scientists look comes from jigsaws, drawn in science lessons, seen pictures, been to see a doctor and they have worn a white coat

- Pupils are used to asking questions if they do not know something or if a medicine has not made them well, another one or the same one has been tried again.

- A feeling that scientists are clever so they make complicated things. Life experiences such as television, books, school, friends and family are the methods that supply knowledge, share interests, develops hobbies to this age group. This age group of pupils appear to have a good knowledge of scientists and a lot of enthusiasm for their school science lessons, however, there was a mixed attitude towards whether they would want to be a scientist or pursue scientific activities in their leisure time. 


\section{Results: Yr 6}

Bar chart representation confirmed that the attitudes look stable over time since they are similar in both the pre and post tests. This was confirmed by the chi square statistic which showed no difference in attitude was measured in the pre and post test. The means show that the themes which pupils are positive in attitude are: attitude toward scientific inquiry, in the pre test toward adoption of a scientific attitude and in the post test normality of scientists. The standard deviations show that there is a degree of spread in some of the responses for some of the questions. This is especially noticeable in themes six and seven (leisure and career interests in science) (and in the pre test theme five (enjoyment of science lessons)). (see Tables III and IV)

For chi square to be significant $p<0.05$ and $p<0.01$ levels, the chi square statistic would have to be 3.84 or 6.63 respectively ( 1 degree of freedom). For $13 \mathrm{df}$ chi square values would need to be 22.36 or 27.68 $(p<0.05$ and $p<0.01$ respectively) (see Table $V$ for chi square results for each of Klopfer's themes). The null hypothesis 'there is no difference in attitude as measured in the pre and post test' is therefore accepted and this showed that there is no change in attitude between the two tests.

Analysis of the pre and post TOSRA data and gender issues showed some patterns. In Yr 6, it was the girls, when comparing the mean values in each of the seven themes, who had more of them that were higher than the boys mean values in the seven themes. 
The $\operatorname{Yr} 6$ results show that the themes with the highest means are themes three and four (see Figure 5). This shows that pupils know what they should do in science lessons to be scientific. However, the themes with the lowest means are themes six and seven showing that pupils do not undertake scientific activities in their leisure time (or one would argue what they would perceive to be scientific) or express an interest in a scientific career.

Comparing the boys:girls ratio also show that the means are quite close. This may be surprising as it could be expected for boys to show a more positive attitude than girls but this is not evident from the results.

Triangulating with the pilot study undertaken with the previous year's cohort and their responses to the questions, all of the themes are under a mean difference of 0.5 (see Tables VI and VII (previous year is $\mathrm{Yr} 1$ of study in the table). With the exception of theme five in the post test, all of the means decrease from the previous year. This provides some degree of strength to the results that two different cohorts of the same age groups had similar results on this questionnaire.

These results confirm that the pupils' attitudes in $\mathrm{Yr} 6$ are fixed before the beginning of the year as they do not change throughout the year.

To gain more insight into pupils' attitudes, additional ranking questions were added to the questionnaire. Favourite subject and science varies from 
one school to the next. The most useful information was that regarding what pupils like to do in lessons (see Figure 6).

One of the main influences on young primary school children is their teacher and a simple questionnaire was designed, following the main study involving the pupils, to probe deeper into how teachers feel about teaching science compared to which subject they were trained in to teach (see Appendix 3 ). From the questionnaire findings, all of the teachers who participated from the six schools (opportunistic sample) showed a positive enjoyment of teaching science, regardless of whether they were trained in it or not. Science being a core subject in the National Curriculum since 1989 had many primary school teachers attend INSET training in science teaching. This was due to the DES (1985) stating that many primary school teachers had a poor scientific knowledge base (Pell and Jarvis, 2001). However, this was not apparent in the schools that participated; the teachers enjoyed teaching science and felt confident to do so. Teachers need to be confident to allow pupils to explore and to sometimes admit they do not know an answer (Jarvis, 1991). Science is a subject that can be explored and enjoyed by all that are involved due to its changing nature:

'Science is exciting for teachers and pupils alike' (Jarvis, 1991, p.5).

Pollard et al. (1994) also showed that: 
'...teachers' moral and personal commitment to the education of young children remained strong, despite the pressures on them' ( $p$. 236).

This is echoed in the results of this questionnaire and certainly showed that teachers were committed to teaching science well.

The lesson observations showed that pupils in Yr 6 appeared to enjoy the activities undertaken in lessons and they asked inquisitive and deep questions. The level of work completed by the pupils was impressive and the pupils enjoyed using the science laboratory facility. The teachers used practicals wherever possible and pupils liked the Interactive Whiteboard used.

The results from this study show that younger pupils have an abundance of enthusiasm towards science. The older primary school pupils show they are positive toward some of Klopfer's themes, however, their enjoyment and leisure/career interest is not as convincing. The question of when exactly do pupils' attitudes change, is not exactly known but it appears to be between Yrs 2 and 6 .

\section{Conclusion and Discussion}

This study has shown that pupils' attitudes towards science are mainly set at an early age in primary school. This emphasises the importance of science and its place in the primary curriculum, and highlights the need for urgent attention to readdress primary science if teachers are to motivate more pupils 
to follow scientific careers in the future. The Yr 2 pupils' enthusiasm for their science lessons diminishes as they proceed through primary school meaning that some pupils reach secondary school feeling hostile towards science. The results for pupils in $\operatorname{Yr} 6$ showed that, for the majority of pupils, attitudes towards science are already fixed. This study supports the findings of Ormerod and Duckworth (1975), that primary ages are critical for a child's formation of a positive attitude towards science.

The results from this study also concur with Stables (1990) in that younger pupils demonstrate a more positive attitude towards school science than older pupils. This is also consistent with findings from Choppin (1974), Hadden and Johnstone (1983) and Kelly (1986). Murphy and Beggs (2003) also echoed this finding:

'..most of the older children (10/11years) had significantly less positive attitudes than younger ones (8/9years) towards science enjoyment, even though the older children were more confident about their ability to do science' (p. 113).

Some suggested reasons why older pupils' attitudes are less positive than younger pupils by Murphy and Beggs (2003) are:

- Lack of experimental work;

- Repetition of topics;

- Focus on national tests in lessons;

- Inappropriate science curriculum content. 
It is these points that need to be considered when reviewing the primary curriculum.

Encouragingly, teachers who participated in the research are emphatic in their support of science teaching. In order to enhance pupils' attitudes towards science, this work suggests promoting everyday experiences of science and would encourage parents, teachers and the media to work together to promote and excite pupils about science.

Other research concurs with this study's results and earlier work points towards some suggestions for further work to be undertaken. For example, data reported from Hadden and Johnstone (1983) showed that pupils' attitudes showed no improvement from the age of nine so research of this age group and younger is required. It is, therefore, not surprising that pupils display a negative attitude towards secondary science (Barmby et al., 2008; Owen et al., 2008); pupils' attitudes are fixed during primary school and therefore intervention needs to take place within the primary classroom. If we genuinely believe to have the need for more scientists and science-related careers, attention to pupils' attitudes in the primary school is imperative.

The necessity for primary teachers to encourage and nurture pupils in their science learning could be assisted by creative planning and teaching. Pollard et al. (1994) reported reasons why pupils liked certain classroom activities:

- Interesting;

- Brought success; 
- Fun.

Planning novel and different activities which incorporate success and fun for the pupils could help improve pupils' attitudes. Activities that were disliked by pupils, as they caused boredom, were:

- Difficult tasks;

- $\quad$ Sitting down tasks;

- Listening;

- Writing.

It is these simple but vital points that can influence a pupil's enjoyment and attitude towards a subject. Science is a subject which offers variety and excitement for its pupils. The data and conclusions presented by this study offer proposals for the ways in which science curriculum and teaching might develop in the future.

\section{References}

Barmby, P., P.M. Kind, and K. Jones. 2008. Examining Changing Attitudes in Secondary School Science. International Journal of Science Education 30, no. 8: 1075-1093.

Braund, Martin, and Mike Driver. 2002. Moving to the big school: what do pupils think about science practical work pre- and post- transfer? Paper presented at the annual conference of the British Educational Research Association, September 12-14, Exeter, England.

http://www.leeds.ac.uk/educol/documents/00002157.htm.

Breakwell, G.M., and S. Beardsell. 1992. Gender, parental and peer influences upon science attitudes and activities. Public Understanding of Science 1: 183-197. In: J. Osborne, S. Simon and S. Collins. 1992. Attitudes towards science: a review of the literature and its implications. International Journal of Science Education 25, no. 9:1049-1079.

Choppin, B. 1974. The introduction of new science curricula in England and Wales. Comparative Education Review 18:196-202. 
Cohen, L., and L. Manion. 1980. Research Methods in Education. Kent: Croom Helm.

Cohen, L., L. Manion, and K. Morrison. 2007. Research Methods in Education. Oxford: Routledge.

DES.1985. Science 5 -16: A Statement of Policy. London: HMSO.

Dowling, P. 2001. The teaching challenge: science, engineering and the knowledge of economy. School Science Review 82, no. 301: 17-25.

Drever, E. 1997. Using Semi-structured Interviews in Small Scale Research: A Teacher's Guide. Glasgow: SCRE Publications.

Fraser, B.J. 1978. Development of a Test of Science-Related Attitudes. Science Education 62, no. 4: 509-515.

Fraser, B. J. 1981. Test of Science related attitudes: handbook. Victoria: Australia Council for Educational Research.

Hadden, R.A., and A.H. Johnstone. 1983. Secondary school pupils' attitudes to science: the year of erosion. European Journal of Science Education 5: 309-318.

Hofstein, A., N. Maoz, and M. Rishpon. 1990. Attitudes towards school science: a comparison of participants and non-participants in extra-curricular science activities. School Science and Mathematics 90:13-22.

Jarvis, T. 1991. Children and Primary Science. London: Cassel Educational Limited.

Jenkins, E. W. 2004. From option to compulsion: school science teaching, 1954-2004. School Science Review 85, no. 313: 33-40.

Jenkins, E.W., and N.W. Nelson. 2005. Important but not for me: students' attitudes towards secondary school science in England. Research in Science and Technological Education 23, no. 1: 41-57.

Kelly, A. 1986. The development of girls' and boys' attitudes to science: a longitudinal study. European Journal of Science Education 8: 399-412.

Klopfer L.E. 1971. Evaluation of learning in science. In B.S. Bloom, J.T. Hastings, and G.F. Madaus. (eds.) Handbook on summative and formative evaluation of student learning. p. 559-641. New York: McGraw-Hill.

Ledbetter, C.E., and R.K. Nix. 2002. Test of Science Related Skills. Victoria: The Australian Council for Educational Research Limited. 
Lyons, T. 2006. Different Countries, Same Science Classes: Students' experiences of school science in their own words. International Journal of Science Education 28, no. 6: 591-613.

Mortimore, P., P. Sammons, L. Stoll, D. Lewis, and R. Ecob. 1988. School Matters: the junior years. London: Open books publishing Ltd.

Moser, C. A., and G. Kalton. 1977. Survey Methods in Social Investigation. London: Heinemann Educational Books.

Murphy, C., and J. Beggs. 2003. Children's perceptions of school science. School Science Review 84, no. 308: 109 -116.

National Curriculum Council. 1988. Science in the National Curriculum. Surrey: Withyham Production.

Nunnaly, J. 1978. Psychometric theory. In J. Reynaldo and A. Santos. 1999. Cronbach's Alpha: A Tool for Assessing the Reliability of Scales. Journal of Extension 37, no. 2: 1-5. http://www.joe.org/joe/1999April/tt3.html.

Oppenheim, A. N. 1992. Questionnaire Design, Interviewing and Attitude Measurement. $2^{\text {nd }}$ edition. London: Pinter Publishers Ltd.

Ormerod, M. B., and D. Duckworth. 1975. Pupil's attitudes to science. Berks: NFER Publishing Company.

Osborne, J., R. Driver, and S. Simon. 1998. Attitudes to science: Issues and concerns. School Science Review 79, no. 288: 27-33.

Owen, S., D. Dickson, M. Stanisstreet, and E. Boyes. 2008. Teaching physics: Students' attitudes towards different learning activities. Research in Science and Technological Education 26, no. 2: 113-128.

Pell, T., and T. Jarvis. 2001. Developing Attitude to Science Scales for use with Children of Ages from five to eleven years. International Journal of Science Education 23, no. 8: 847-862.

Piburn, M. D., and D.R. Baker. 1993. If I were the Teacher...Qualitative Study of Attitude Toward Science. Science Education 77, no. 4: 393-406.

Pollard, A., C. Broadfoot, P. Croll, M. Osborn, and D. Abbott. 1994. Changing English Primary Schools: the impact of the Education Reform Act at Key Stage One. London: Cassell.

QCA. 1999. National Curriculum for Science. London: QCA.

Simpson, R.D., and J.S. Oliver. 1985. Attitude toward science and achievement motivation profiles of male and female science students in grades six through ten. Science Education 69, no. 4: 511-526. 
Stables, A. 1990. Differences between Pupils from Mixed and Single-sex Schools in Their Enjoyment of School Subjects and in Their Attitudes to Science and to School. Educational Review 42, no. 3: 221-230.

Turner, S. 2008. Pupils' Attitudes towards Primary and Secondary Science. Unpublished MPhil. Loughborough University.

Ward, Helen. 2009. Tomorrow's primaries: 2 reviews, 1 debate. Times Educational Supplement, February 20, News section, London.

West, A., J. Hailes, and P. Sammons. 1997. Children's Attitudes to the National Curriculum at Key Stage 1. British Educational Research Journal 23, no. 5: 597-613. 


\section{Appendix 1: Pilot Study}

\section{Pre Test What do YOU think about Science?}

Your responses are completely confidential. Your participation is voluntary.

Gender: male/female

Age:

Please indicate whether you Strongly Agree, Agree, are Not Sure, Disagree, Strongly Disagree with each statement by circling your best response.

\begin{tabular}{|c|c|c|c|c|c|c|}
\hline $\begin{array}{l}\text { Strongly } \\
\text { agree }\end{array}$ & Agree & Not Sure & Disagree & $\begin{array}{l}\text { Strongly } \\
\quad \text { disagree }\end{array}$ & 1 & $\begin{array}{l}\text { Money spent on science is well } \\
\text { worth spending }\end{array}$ \\
\hline $\begin{array}{l}\text { Strongly } \\
\text { agree }\end{array}$ & Agree & Not Sure & Disagree & $\begin{array}{l}\text { Strongly } \\
\quad \text { disagree }\end{array}$ & 2 & $\begin{array}{l}\text { When scientists have a day off, } \\
\text { they spend it with their families, not } \\
\text { in their laboratory }\end{array}$ \\
\hline $\begin{array}{l}\text { Strongly } \\
\text { agree }\end{array}$ & Agree & Not Sure & Disagree & $\begin{array}{l}\text { Strongly } \\
\quad \text { disagree }\end{array}$ & 3 & $\begin{array}{l}\text { I would rather find out why } \\
\text { something happens by doing an } \\
\text { experiment than by being told how } \\
\text { it works }\end{array}$ \\
\hline $\begin{array}{l}\text { Strongly } \\
\text { agree }\end{array}$ & Agree & Not Sure & Disagree & $\begin{array}{l}\text { Strongly } \\
\quad \text { disagree }\end{array}$ & 4 & $\begin{array}{l}\text { I find it interesting to hear about } \\
\text { new ideas }\end{array}$ \\
\hline $\begin{array}{l}\text { Strongly } \\
\text { agree }\end{array}$ & Agree & Not Sure & Disagree & $\begin{array}{l}\text { Strongly } \\
\quad \text { disagree }\end{array}$ & 5 & Science lessons are fun \\
\hline $\begin{array}{l}\text { Strongly } \\
\text { agree }\end{array}$ & Agree & Not Sure & Disagree & $\begin{array}{l}\text { Strongly } \\
\quad \text { disagree }\end{array}$ & 6 & $\begin{array}{l}\text { I would like to belong to a science } \\
\text { club }\end{array}$ \\
\hline $\begin{array}{l}\text { Strongly } \\
\text { agree }\end{array}$ & Agree & Not Sure & Disagree & $\begin{array}{l}\text { Strongly } \\
\quad \text { disagree }\end{array}$ & 7 & I would like a job as a scientist \\
\hline $\begin{array}{l}\text { Strongly } \\
\text { agree }\end{array}$ & Agree & Not Sure & Disagree & $\begin{array}{l}\text { Strongly } \\
\quad \text { disagree }\end{array}$ & 8 & $\begin{array}{l}\text { Scientific discoveries are doing } \\
\text { good in the world }\end{array}$ \\
\hline $\begin{array}{l}\text { Strongly } \\
\text { agree }\end{array}$ & Agree & Not Sure & Disagree & $\begin{array}{l}\text { Strongly } \\
\quad \text { disagree }\end{array}$ & 9 & $\begin{array}{l}\text { Scientists are about as fit and } \\
\text { healthy and enjoy sports just as } \\
\text { much as other people }\end{array}$ \\
\hline $\begin{array}{l}\text { Strongly } \\
\text { agree }\end{array}$ & Agree & Not Sure & Disagree & $\begin{array}{l}\text { Strongly } \\
\quad \text { disagree }\end{array}$ & 10 & $\begin{array}{l}\text { Doing experiments helps me to } \\
\text { learn just as much as finding out } \\
\text { from teachers }\end{array}$ \\
\hline
\end{tabular}




\begin{tabular}{|c|c|c|c|c|c|c|}
\hline $\begin{array}{l}\text { Strongly } \\
\text { agree }\end{array}$ & Agree & Not Sure & Disagree & $\begin{array}{l}\text { Strongly } \\
\quad \text { disagree }\end{array}$ & 11 & $\begin{array}{l}\text { In science experiments, I like to } \\
\text { use methods that I have not used } \\
\text { before }\end{array}$ \\
\hline $\begin{array}{l}\text { Strongly } \\
\text { agree }\end{array}$ & Agree & Not Sure & Disagree & $\begin{array}{l}\text { Strongly } \\
\quad \text { disagree }\end{array}$ & 12 & $\begin{array}{l}\text { School should have more science } \\
\text { lessons per week }\end{array}$ \\
\hline $\begin{array}{l}\text { Strongly } \\
\text { agree }\end{array}$ & Agree & Not Sure & Disagree & $\begin{array}{l}\text { Strongly } \\
\quad \text { disagree }\end{array}$ & 13 & $\begin{array}{l}\text { I enjoy watching science programs } \\
\text { on television }\end{array}$ \\
\hline $\begin{array}{l}\text { Strongly } \\
\text { agree }\end{array}$ & Agree & Not Sure & Disagree & $\begin{array}{l}\text { Strongly } \\
\text { disagree }\end{array}$ & 14 & $\begin{array}{l}\text { I would like to work with people } \\
\text { who make discoveries in science }\end{array}$ \\
\hline $\begin{array}{l}\text { Strongly } \\
\text { agree }\end{array}$ & Agree & Not Sure & Disagree & $\begin{array}{l}\text { Strongly } \\
\quad \text { disagree }\end{array}$ & 15 & $\begin{array}{l}\text { The government should spend } \\
\text { more money on scientific research }\end{array}$ \\
\hline $\begin{array}{l}\text { Strongly } \\
\text { agree }\end{array}$ & Agree & Not Sure & Disagree & $\begin{array}{l}\text { Strongly } \\
\quad \text { disagree }\end{array}$ & 16 & $\begin{array}{l}\text { Scientists are just as friendly as } \\
\text { non-scientists }\end{array}$ \\
\hline $\begin{array}{l}\text { Strongly } \\
\text { agree }\end{array}$ & Agree & Not Sure & Disagree & $\begin{array}{l}\text { Strongly } \\
\quad \text { disagree }\end{array}$ & 17 & $\begin{array}{l}\text { I would rather do an experiment } \\
\text { and reach a conclusion myself than } \\
\text { just agree with other people }\end{array}$ \\
\hline $\begin{array}{l}\text { Strongly } \\
\text { agree }\end{array}$ & Agree & Not Sure & Disagree & $\begin{array}{l}\text { Strongly } \\
\quad \text { disagree }\end{array}$ & 18 & $\begin{array}{l}\text { In science lessons, it is good to } \\
\text { report unexpected results as well } \\
\text { as expected ones }\end{array}$ \\
\hline $\begin{array}{l}\text { Strongly } \\
\text { agree }\end{array}$ & Agree & Not Sure & Disagree & $\begin{array}{l}\text { Strongly } \\
\quad \text { disagree }\end{array}$ & 19 & $\begin{array}{l}\text { Science is one of the most } \\
\text { interesting school subjects }\end{array}$ \\
\hline $\begin{array}{l}\text { Strongly } \\
\text { agree }\end{array}$ & Agree & Not Sure & Disagree & $\begin{array}{l}\text { Strongly } \\
\quad \text { disagree }\end{array}$ & 20 & $\begin{array}{l}\text { I would like to be given a science } \\
\text { book or piece of scientific } \\
\text { equipment as a present }\end{array}$ \\
\hline $\begin{array}{l}\text { Strongly } \\
\text { agree }\end{array}$ & Agree & Not Sure & Disagree & $\begin{array}{l}\text { Strongly } \\
\text { disagree }\end{array}$ & 21 & $\begin{array}{l}\text { I would like to work in a science } \\
\text { laboratory }\end{array}$ \\
\hline
\end{tabular}




\section{Post Test What do YOU think about Science?}

Your responses are completely confidential. Your participation is voluntary.

Gender: male/female

Age:

Please indicate whether you Strongly Agree, Agree, are Not Sure, Disagree, Strongly Disagree with each statement by circling your best response.

\begin{tabular}{|c|c|c|c|c|c|c|}
\hline $\begin{array}{l}\text { Strongly } \\
\text { agree }\end{array}$ & Agree & Not Sure & Disagree & $\begin{array}{l}\text { Strongly } \\
\quad \text { disagree }\end{array}$ & 1 & $\begin{array}{l}\text { Laboratories are being built to be } \\
\text { used for scientific research and this } \\
\text { is good for society }\end{array}$ \\
\hline $\begin{array}{l}\text { Strongly } \\
\text { agree }\end{array}$ & Agree & Not Sure & Disagree & $\begin{array}{l}\text { Strongly } \\
\quad \text { disagree }\end{array}$ & 2 & $\begin{array}{l}\text { A scientist can have a normal } \\
\text { family life }\end{array}$ \\
\hline $\begin{array}{l}\text { Strongly } \\
\text { agree }\end{array}$ & Agree & Not Sure & Disagree & $\begin{array}{l}\text { Strongly } \\
\quad \text { disagree }\end{array}$ & 3 & $\begin{array}{l}\text { I would rather find out about things } \\
\text { by doing an experiment than asking } \\
\text { an expert }\end{array}$ \\
\hline $\begin{array}{l}\text { Strongly } \\
\text { agree }\end{array}$ & Agree & Not Sure & Disagree & $\begin{array}{l}\text { Strongly } \\
\quad \text { disagree }\end{array}$ & 4 & $\begin{array}{l}\text { I enjoy reading about things that } \\
\text { challenge my existing ideas }\end{array}$ \\
\hline $\begin{array}{l}\text { Strongly } \\
\text { agree }\end{array}$ & Agree & Not Sure & Disagree & $\begin{array}{l}\text { Strongly } \\
\quad \text { disagree }\end{array}$ & 5 & $\begin{array}{l}\text { Science lessons are valuable for } \\
\text { learning about everyday life }\end{array}$ \\
\hline $\begin{array}{l}\text { Strongly } \\
\text { agree }\end{array}$ & Agree & Not Sure & Disagree & $\begin{array}{l}\text { Strongly } \\
\quad \text { disagree }\end{array}$ & 6 & $\begin{array}{l}\text { Talking to friends about science } \\
\text { outside of school would be } \\
\text { interesting }\end{array}$ \\
\hline $\begin{array}{l}\text { Strongly } \\
\text { agree }\end{array}$ & Agree & Not Sure & Disagree & $\begin{array}{l}\text { Strongly } \\
\text { disagree }\end{array}$ & 7 & $\begin{array}{l}\text { I would like a career teaching } \\
\text { science }\end{array}$ \\
\hline $\begin{array}{l}\text { Strongly } \\
\text { agree }\end{array}$ & Agree & Not Sure & Disagree & $\begin{array}{l}\text { Strongly } \\
\quad \text { disagree }\end{array}$ & 8 & Science helps make life better \\
\hline $\begin{array}{l}\text { Strongly } \\
\text { agree }\end{array}$ & Agree & Not Sure & Disagree & $\begin{array}{l}\text { Strongly } \\
\quad \text { disagree }\end{array}$ & 9 & $\begin{array}{l}\text { Scientists care about their working } \\
\text { conditions }\end{array}$ \\
\hline $\begin{array}{l}\text { Strongly } \\
\text { agree }\end{array}$ & Agree & Not Sure & Disagree & $\begin{array}{l}\text { Strongly } \\
\quad \text { disagree }\end{array}$ & 10 & $\begin{array}{l}\text { I would rather solve problems to } \\
\text { answer a question than to read the } \\
\text { answer in a magazine }\end{array}$ \\
\hline
\end{tabular}




\begin{tabular}{|c|c|c|c|c|c|c|}
\hline $\begin{array}{l}\text { Strongly } \\
\text { agree }\end{array}$ & Agree & Not Sure & Disagree & $\begin{array}{l}\text { Strongly } \\
\quad \text { disagree }\end{array}$ & 11 & $\begin{array}{l}\text { I realise the importance of taking } \\
\text { repeats in an experiment to check } \\
\text { the results }\end{array}$ \\
\hline $\begin{array}{l}\text { Strongly } \\
\text { agree }\end{array}$ & Agree & Not Sure & Disagree & $\begin{array}{l}\text { Strongly } \\
\text { disagree }\end{array}$ & 12 & I enjoy science lessons \\
\hline $\begin{array}{l}\text { Strongly } \\
\text { agree }\end{array}$ & Agree & Not Sure & Disagree & $\begin{array}{l}\text { Strongly } \\
\text { disagree }\end{array}$ & 13 & $\begin{array}{l}\text { I would love to have a job in } \\
\text { science during my school holidays }\end{array}$ \\
\hline $\begin{array}{l}\text { Strongly } \\
\text { agree }\end{array}$ & Agree & Not Sure & Disagree & $\begin{array}{l}\text { Strongly } \\
\text { disagree }\end{array}$ & 14 & $\begin{array}{l}\text { A job as a scientist would be very } \\
\text { exciting and interesting }\end{array}$ \\
\hline $\begin{array}{l}\text { Strongly } \\
\text { agree }\end{array}$ & Agree & Not Sure & Disagree & $\begin{array}{l}\text { Strongly } \\
\quad \text { disagree }\end{array}$ & 15 & $\begin{array}{l}\text { This country is not spending } \\
\text { enough money on science }\end{array}$ \\
\hline $\begin{array}{l}\text { Strongly } \\
\text { agree }\end{array}$ & Agree & Not Sure & Disagree & $\begin{array}{l}\text { Strongly } \\
\quad \text { disagree }\end{array}$ & 16 & $\begin{array}{l}\text { Scientists are just as interested in } \\
\text { art and music as other people are }\end{array}$ \\
\hline $\begin{array}{l}\text { Strongly } \\
\text { agree }\end{array}$ & Agree & Not Sure & Disagree & $\begin{array}{l}\text { Strongly } \\
\quad \text { disagree }\end{array}$ & 17 & $\begin{array}{l}\text { I enjoy scientific experiments } \\
\text { because I learn a lot from them }\end{array}$ \\
\hline $\begin{array}{l}\text { Strongly } \\
\text { agree }\end{array}$ & Agree & Not Sure & Disagree & $\begin{array}{l}\text { Strongly } \\
\quad \text { disagree }\end{array}$ & 18 & $\begin{array}{l}\text { I am curious about the world in } \\
\text { which we live }\end{array}$ \\
\hline $\begin{array}{l}\text { Strongly } \\
\text { agree }\end{array}$ & Agree & Not Sure & Disagree & $\begin{array}{l}\text { Strongly } \\
\text { disagree }\end{array}$ & 19 & $\begin{array}{l}\text { Material covered in science lessons } \\
\text { is interesting }\end{array}$ \\
\hline $\begin{array}{l}\text { Strongly } \\
\text { agree }\end{array}$ & Agree & Not Sure & Disagree & $\begin{array}{l}\text { Strongly } \\
\quad \text { disagree }\end{array}$ & 20 & $\begin{array}{l}\text { Listening to science reports on the } \\
\text { radio is really interesting }\end{array}$ \\
\hline $\begin{array}{l}\text { Strongly } \\
\text { agree }\end{array}$ & Agree & Not Sure & Disagree & $\begin{array}{l}\text { Strongly } \\
\quad \text { disagree }\end{array}$ & 21 & $\begin{array}{l}\text { Being a scientist would be an } \\
\text { interesting career }\end{array}$ \\
\hline
\end{tabular}


Appendix 2: Main Study Pre Test What do YOU think about Science?

Your responses are completely confidential. Your participation is voluntary.

Gender: male/female

Age:

Please indicate whether you Strongly Agree, Agree, are Not Sure, Disagree, Strongly Disagree with each statement by circling your best response.

\begin{tabular}{|c|c|c|c|c|c|c|}
\hline $\begin{array}{l}\text { Strongly } \\
\text { agree }\end{array}$ & Agree & Not Sure & Disagree & $\begin{array}{l}\text { Strongly } \\
\text { disagree }\end{array}$ & 1 & $\begin{array}{l}\text { Scientific discoveries are } \\
\text { doing good in the world }\end{array}$ \\
\hline $\begin{array}{l}\text { Strongly } \\
\text { agree }\end{array}$ & Agree & Not Sure & Disagree & $\begin{array}{l}\text { Strongly } \\
\quad \text { disagree }\end{array}$ & 2 & $\begin{array}{l}\text { Scientists are about as fit and } \\
\text { healthy and enjoy sports just as } \\
\text { much as other people }\end{array}$ \\
\hline $\begin{array}{l}\text { Strongly } \\
\text { agree }\end{array}$ & Agree & Not Sure & Disagree & $\begin{array}{l}\text { Strongly } \\
\quad \text { disagree }\end{array}$ & 3 & $\begin{array}{l}\text { I would rather find out why } \\
\text { something happens by doing an } \\
\text { experiment than by being told }\end{array}$ \\
\hline $\begin{array}{l}\text { Strongly } \\
\text { agree }\end{array}$ & Agree & Not Sure & Disagree & $\begin{array}{l}\text { Strongly } \\
\text { disagree }\end{array}$ & 4 & $\begin{array}{l}\text { I find it interesting to hear about } \\
\text { new ideas }\end{array}$ \\
\hline $\begin{array}{l}\text { Strongly } \\
\text { agree }\end{array}$ & Agree & Not Sure & Disagree & $\begin{array}{l}\text { Strongly } \\
\quad \text { disagree }\end{array}$ & 5 & Science lessons are fun \\
\hline $\begin{array}{l}\text { Strongly } \\
\text { agree }\end{array}$ & Agree & Not Sure & Disagree & $\begin{array}{l}\text { Strongly } \\
\quad \text { disagree }\end{array}$ & 6 & $\begin{array}{l}\text { I would like to belong to a } \\
\text { science club to try new } \\
\text { experiments }\end{array}$ \\
\hline $\begin{array}{l}\text { Strongly } \\
\text { agree }\end{array}$ & Agree & Not Sure & Disagree & $\begin{array}{l}\text { Strongly } \\
\text { disagree }\end{array}$ & 7 & $\begin{array}{l}\text { I would like to work with people } \\
\text { who make discoveries in science }\end{array}$ \\
\hline $\begin{array}{l}\text { Strongly } \\
\text { agree }\end{array}$ & Agree & Not Sure & Disagree & $\begin{array}{l}\text { Strongly } \\
\quad \text { disagree }\end{array}$ & 8 & $\begin{array}{l}\text { The government should spend } \\
\text { more money on scientific } \\
\text { research }\end{array}$ \\
\hline $\begin{array}{l}\text { Strongly } \\
\text { agree }\end{array}$ & Agree & Not Sure & Disagree & $\begin{array}{l}\text { Strongly } \\
\text { disagree }\end{array}$ & 9 & $\begin{array}{l}\text { Scientists are just as friendly as } \\
\text { non-scientists }\end{array}$ \\
\hline $\begin{array}{l}\text { Strongly } \\
\text { agree }\end{array}$ & Agree & Not Sure & Disagree & $\begin{array}{l}\text { Strongly } \\
\quad \text { disagree }\end{array}$ & 10 & $\begin{array}{l}\text { Doing experiments helps me to } \\
\text { learn just as much as finding out } \\
\text { from teachers and books }\end{array}$ \\
\hline $\begin{array}{l}\text { Strongly } \\
\text { agree }\end{array}$ & Agree & Not Sure & Disagree & $\begin{array}{l}\text { Strongly } \\
\text { disagree }\end{array}$ & 11 & $\begin{array}{l}\text { In science lessons, it is good to } \\
\text { report unexpected results as well } \\
\text { as expected ones }\end{array}$ \\
\hline $\begin{array}{l}\text { Strongly } \\
\text { agree }\end{array}$ & Agree & Not Sure & Disagree & $\begin{array}{l}\text { Strongly } \\
\quad \text { disagree }\end{array}$ & 12 & $\begin{array}{l}\text { Science is one of the most } \\
\text { interesting school subjects }\end{array}$ \\
\hline $\begin{array}{l}\text { Strongly } \\
\text { agree }\end{array}$ & Agree & Not Sure & Disagree & $\begin{array}{l}\text { Strongly } \\
\quad \text { disagree }\end{array}$ & 13 & $\begin{array}{l}\text { I enjoy watching science } \\
\text { programs on the television }\end{array}$ \\
\hline $\begin{array}{l}\text { Strongly } \\
\text { agree }\end{array}$ & Agree & Not Sure & Disagree & $\begin{array}{l}\text { Strongly } \\
\quad \text { disagree }\end{array}$ & 14 & $\begin{array}{l}\text { I would like to work in a scientific } \\
\text { laboratory finding out new things }\end{array}$ \\
\hline
\end{tabular}


From the following lists of school subjects, rank your favourite to least favourite by numbering $1-5$ (1=favourite -5 least favourite).

1

\begin{tabular}{|l|l|}
\hline School Subject & $\begin{array}{l}\text { Rank from Favourite (1) to Least } \\
\text { Favourite (5) }\end{array}$ \\
\hline Maths & \\
\hline English & \\
\hline Science & \\
\hline Geography & \\
\hline French & \\
\hline
\end{tabular}

\begin{tabular}{|l|l|}
\hline School Subject & $\begin{array}{l}\text { Rank from Favourite (1) to Least } \\
\text { Favourite (5) }\end{array}$ \\
\hline Science & \\
\hline Technology & \\
\hline Art & \\
\hline Music & \\
\hline Physical Education & \\
\hline
\end{tabular}

3

\begin{tabular}{|l|l|}
\hline School Subject & $\begin{array}{l}\text { Rank from Favourite (1) to Least } \\
\text { Favourite (5) }\end{array}$ \\
\hline English & \\
\hline History & \\
\hline Science & \\
\hline Technology & \\
\hline ICT & \\
\hline
\end{tabular}

\begin{tabular}{|l|l|}
\hline Science Subject & $\begin{array}{l}\text { Rank from Favourite (1) to Least } \\
\text { Favourite (3) }\end{array}$ \\
\hline Biology & \\
\hline Chemistry & \\
\hline Physics & \\
\hline
\end{tabular}

5 Tick any of the following reasons why you particularly like a school subject.

\begin{tabular}{|l|l|l|l|}
\hline Reason & Tick $\checkmark$ & Reason & $\begin{array}{l}\text { Tick } \\
\checkmark\end{array}$ \\
\hline It's practically-based & & Field trips & \\
\hline Like the teacher & & Lots of videos & \\
\hline Interesting topics & & Use computers a lot & \\
\hline Can use my imagination & & $\begin{array}{l}\text { Like thinking and solving } \\
\text { puzzles }\end{array}$ & \\
\hline
\end{tabular}




\section{(Post Test) What do YOU think about Science?}

Your responses are completely confidential. Your participation is voluntary.

Gender: male/female

Age:

Please indicate whether you Strongly Agree, Agree, are Not Sure, Disagree, Strongly Disagree with each statement by circling your best response.

\begin{tabular}{|c|c|c|c|c|c|c|}
\hline $\begin{array}{l}\text { Strongly } \\
\text { agree }\end{array}$ & Agree & Not Sure & Disagree & $\begin{array}{l}\text { Strongly } \\
\quad \text { disagree }\end{array}$ & 1 & $\begin{array}{l}\text { Laboratories are being built to be } \\
\text { used for scientific research and } \\
\text { this is good for society }\end{array}$ \\
\hline $\begin{array}{l}\text { Strongly } \\
\text { agree }\end{array}$ & Agree & Not Sure & Disagree & $\begin{array}{l}\text { Strongly } \\
\quad \text { disagree }\end{array}$ & 2 & $\begin{array}{l}\text { A scientist can have a normal } \\
\text { family life }\end{array}$ \\
\hline $\begin{array}{l}\text { Strongly } \\
\text { agree }\end{array}$ & Agree & Not Sure & Disagree & $\begin{array}{l}\text { Strongly } \\
\quad \text { disagree }\end{array}$ & 3 & $\begin{array}{l}\text { I would rather find out about } \\
\text { things by doing an experiment } \\
\text { than asking an expert }\end{array}$ \\
\hline $\begin{array}{l}\text { Strongly } \\
\text { agree }\end{array}$ & Agree & Not Sure & Disagree & $\begin{array}{l}\text { Strongly } \\
\text { disagree }\end{array}$ & 4 & $\begin{array}{l}\text { I enjoy reading about things that } \\
\text { challenge my existing ideas }\end{array}$ \\
\hline $\begin{array}{l}\text { Strongly } \\
\text { agree }\end{array}$ & Agree & Not Sure & Disagree & $\begin{array}{l}\text { Strongly } \\
\quad \text { disagree }\end{array}$ & 5 & $\begin{array}{l}\text { Science lessons are valuable for } \\
\text { learning about everyday life }\end{array}$ \\
\hline $\begin{array}{l}\text { Strongly } \\
\text { agree }\end{array}$ & Agree & Not Sure & Disagree & $\begin{array}{l}\text { Strongly } \\
\quad \text { disagree }\end{array}$ & 6 & $\begin{array}{l}\text { Talking to friends about science } \\
\text { outside of school would be } \\
\text { interesting }\end{array}$ \\
\hline $\begin{array}{l}\text { Strongly } \\
\text { agree }\end{array}$ & Agree & Not Sure & Disagree & $\begin{array}{l}\text { Strongly } \\
\text { disagree }\end{array}$ & 7 & $\begin{array}{l}\text { I would like a career teaching } \\
\text { science }\end{array}$ \\
\hline $\begin{array}{l}\text { Strongly } \\
\text { agree }\end{array}$ & Agree & Not Sure & Disagree & $\begin{array}{l}\text { Strongly } \\
\text { disagree }\end{array}$ & 8 & Science helps make life better \\
\hline $\begin{array}{l}\text { Strongly } \\
\text { agree }\end{array}$ & Agree & Not Sure & Disagree & $\begin{array}{l}\text { Strongly } \\
\quad \text { disagree }\end{array}$ & 9 & $\begin{array}{l}\text { Scientists care about their } \\
\text { working conditions }\end{array}$ \\
\hline $\begin{array}{l}\text { Strongly } \\
\text { agree }\end{array}$ & Agree & Not Sure & Disagree & $\begin{array}{l}\text { Strongly } \\
\text { disagree }\end{array}$ & 10 & $\begin{array}{l}\text { I enjoy scientific experiments } \\
\text { because I learn a lot from them }\end{array}$ \\
\hline $\begin{array}{l}\text { Strongly } \\
\text { agree }\end{array}$ & Agree & Not Sure & Disagree & $\begin{array}{l}\text { Strongly } \\
\quad \text { disagree }\end{array}$ & 11 & $\begin{array}{l}\text { I am curious about the world in } \\
\text { which we live }\end{array}$ \\
\hline $\begin{array}{l}\text { Strongly } \\
\text { agree }\end{array}$ & Agree & Not Sure & Disagree & $\begin{array}{l}\text { Strongly } \\
\quad \text { disagree }\end{array}$ & 12 & $\begin{array}{l}\text { The material covered in science } \\
\text { lessons is interesting }\end{array}$ \\
\hline $\begin{array}{l}\text { Strongly } \\
\text { agree }\end{array}$ & Agree & Not Sure & Disagree & $\begin{array}{l}\text { Strongly } \\
\quad \text { disagree }\end{array}$ & 13 & $\begin{array}{l}\text { Listening to science reports on } \\
\text { the radio is really interesting }\end{array}$ \\
\hline $\begin{array}{l}\text { Strongly } \\
\text { agree }\end{array}$ & Agree & Not Sure & Disagree & $\begin{array}{l}\text { Strongly } \\
\quad \text { disagree }\end{array}$ & 14 & $\begin{array}{l}\text { A job as a scientist would be very } \\
\text { exciting and interesting }\end{array}$ \\
\hline
\end{tabular}


From the following lists of school subjects, rank your favourite to least favourite by numbering $1-5$ (1=favourite -5 least favourite).

1

\begin{tabular}{|l|l|}
\hline School Subject & $\begin{array}{l}\text { Rank from Favourite (1) to Least } \\
\text { Favourite (5) }\end{array}$ \\
\hline Maths & \\
\hline English & \\
\hline Science & \\
\hline Geography & \\
\hline French & \\
\hline
\end{tabular}

\begin{tabular}{|l|l|}
\hline School Subject & $\begin{array}{l}\text { Rank from Favourite (1) to Least } \\
\text { Favourite (5) }\end{array}$ \\
\hline Science & \\
\hline Technology & \\
\hline Art & \\
\hline Music & \\
\hline Physical Education & \\
\hline
\end{tabular}

3

\begin{tabular}{|l|l|}
\hline School Subject & $\begin{array}{l}\text { Rank from Favourite (1) to Least } \\
\text { Favourite (5) }\end{array}$ \\
\hline English & \\
\hline History & \\
\hline Science & \\
\hline Technology & \\
\hline ICT & \\
\hline
\end{tabular}

\begin{tabular}{|l|l|}
\hline Science Subject & $\begin{array}{l}\text { Rank from Favourite (1) to Least } \\
\text { Favourite (3) }\end{array}$ \\
\hline Biology & \\
\hline Chemistry & \\
\hline Physics & \\
\hline
\end{tabular}

5 Tick any of the following reasons why you particularly like a school subject.

\begin{tabular}{|l|l|l|l|}
\hline Reason & Tick $\checkmark$ & Reason & $\begin{array}{l}\text { Tick } \\
\checkmark\end{array}$ \\
\hline It's practically-based & & Field trips & \\
\hline Like the teacher & & Lots of videos & \\
\hline Interesting topics & & Use computers a lot & \\
\hline Can use my imagination & & $\begin{array}{l}\text { Like thinking and solving } \\
\text { puzzles }\end{array}$ & \\
\hline I'm good at it & & I find it easy & \\
\hline
\end{tabular}




\section{Appendix $3 \quad$ Primary School Subjects}

Your participation is voluntary. All information will be treated as confidential.

Please complete the following details by circling your appropriate response:

Male/Female

Number of Years in teaching: 0-2yrs 3-5yrs 6-10yrs 11-20yrs 30+yrs

$\begin{array}{llllllll}\text { Year Groups taught during career: } & 1 & 2 & 3 & 4 & 5 & 6\end{array}$

Specialist qualification(s) to teach e.g. degree, postgraduate:

Technology

English Maths Science Art ICT

R.S.

Geography History French Music P.E.

Other:

For the following questions, please circle the appropriate response(s) or add a response on the line given:

1 Which subject(s) do you enjoy teaching the most at school?

English Maths Science ICT Art R.S. Geography

Music French Technology Physical Education History

2 Why do you enjoy teaching these subjects?

I'm good at it

Feel confident

Other:
Many resources

Pupils enjoy it
Interesting topics

Practical aspects 
3 Which subject(s) do you lest enjoy teaching at school?
English
Maths
Science
ICT Art
R.S. Geography
Music
French
Technology Physical Education History

\section{PLEASE TURN OVER}

\section{$4 \quad$ Why do you dislike teaching these subjects?}

I'm not good at it

Don't feel confident

Pupils find it hard times

Other:
Not many resources

Pupils don't enjoy it

No training on it myself
Uninteresting topics

No practical aspects

Taught it too many

5 What are your favourite classroom activities in lessons?

Videos

CD-ROMs Interactive Whiteboard

Story-time

Writing Comprehension Practicals Art work

Group work Role-play Demonstrating experiments

Other:

Thank you for your help; it is very much appreciated. 


\section{Tables in the Text}

\begin{tabular}{|c|l|}
\hline Klopfer's Theme & Meaning of each Theme \\
\hline 1 & Social implications of science \\
\hline 2 & Normality of scientists \\
\hline 3 & Attitude towards scientific inquiry \\
\hline 4 & Adoption of scientific attitude \\
\hline 5 & Enjoyment of science lessons \\
\hline 6 & Leisure interest in science \\
\hline 7 & Career interest in science \\
\hline
\end{tabular}

Table I. Klopfer's themes

\begin{tabular}{|l|l|}
\hline Klopfer's Theme & Main Responses \\
\hline 1- Social Implications & Dentist, Doctor, Nurse and Paramedic \\
\hline 2- Normality & Like to read, wears a white coat, smiles, quiet \\
\hline 3- Scientific inquiry & $\begin{array}{l}\text { Repeat an experiment, ask questions, read } \\
\text { books, try a new experiment }\end{array}$ \\
\hline $\begin{array}{l}\text { 4-Adopting a scientific } \\
\text { attitude }\end{array}$ & $\begin{array}{l}\text { Computers, cars, medicines and mobile } \\
\text { phones }\end{array}$ \\
\hline $\begin{array}{l}\text { 5-Enjoyment of } \\
\text { science lessons }\end{array}$ & $\begin{array}{l}\text { Computers, group work, making things, } \\
\text { experiments }\end{array}$ \\
\hline 6- Leisure interest & $\begin{array}{l}\text { Watch television, play with friends, playa } \\
\text { computer games }\end{array}$ \\
\hline 7- Career & $\begin{array}{l}\text { Actor, vet, policeman, school teacher, hair } \\
\text { dresser }\end{array}$ \\
\hline
\end{tabular}

Table II. Word card activity results $-\mathrm{Yr} 2$

\begin{tabular}{|l|l|l|l|l|l|l|l|l|l|l|l|l|l|l|l|}
\hline & Qu & 1 & 2 & 3 & 4 & 5 & 6 & 7 & 8 & 9 & 10 & 11 & 12 & 13 & 14 \\
\hline Yr 6 & $\bar{x}$ & 3.80 & 2.99 & 4.32 & 3.84 & 3.46 & 2.63 & 2.79 & 3.11 & 3.58 & 3.84 & 3.64 & 2.78 & 3.14 & 2.33 \\
\hline & s.d. & 0.73 & 0.90 & 0.85 & 0.75 & 1.25 & 1.33 & 1.17 & 1.25 & 1.08 & 1.10 & 1.04 & 1.39 & 1.36 & 1.33 \\
\hline
\end{tabular}

Table III. 106 pupils; pre test (50\% female:50\% male) 


\begin{tabular}{|l|l|l|l|l|l|l|l|l|l|l|l|l|l|l|l|}
\hline & $\mathrm{Qu}$ & 1 & 2 & 3 & 4 & 5 & 6 & 7 & 8 & 9 & 10 & 11 & 12 & 13 & 14 \\
\hline $\begin{array}{l}\mathrm{Y} \\
\mathrm{r} \\
6\end{array}$ & $\overline{\mathrm{X}}$ & 3.55 & 3.78 & 3.92 & 3.18 & 3.65 & 2.28 & 1.77 & 3.64 & 3.63 & 3.89 & 3.44 & 3.06 & 2.08 & 2.82 \\
\hline & s.d. & 0.70 & 1.08 & 1.16 & 1.18 & 1.02 & 1.18 & 0.98 & 1.09 & 0.87 & 1.04 & 1.12 & 1.01 & 1.10 & 1.33 \\
\hline
\end{tabular}

Table IV. 100 pupils; post test (51\% female:49\% male)

\begin{tabular}{|l|l|l|l|l|l|l|l|}
\hline & $\begin{array}{l}\text { Theme } \\
\mathbf{1}\end{array}$ & $\mathbf{2}$ & $\mathbf{3}$ & $\mathbf{4}$ & $\mathbf{5}$ & $\mathbf{6}$ & $\mathbf{7}$ \\
\hline Pre TOSRA Mean & 3.46 & 3.30 & 4.08 & 3.74 & 3.12 & 2.89 & 2.56 \\
\hline Post TOSRA Mean & 3.60 & 3.71 & 3.91 & 3.31 & 3.36 & 2.18 & 2.30 \\
\hline chi square & 0.76 & 0.68 & 0.84 & 0.70 & 0.85 & 0.44 & 0.41 \\
\hline
\end{tabular}

Table V. Chi square result for each theme

\begin{tabular}{|c|c|c|c|}
\hline Klopfer's Theme & $\begin{array}{l}\text { Pilot Study } \\
\text { Mean Result }\end{array}$ & $\begin{array}{l}\text { Main Study } \\
\text { Mean Result }\end{array}$ & Difference \\
\hline 1 & 3.69 & 3.46 & 0.23 \\
\hline 2 & 3.43 & 3.29 & 0.13 \\
\hline 3 & 4.08 & 4.08 & 0.00 \\
\hline 4 & 3.78 & 3.74 & 0.04 \\
\hline 5 & 3.24 & 3.12 & 0.12 \\
\hline 6 & 2.95 & 2.89 & 0.06 \\
\hline 7 & 2.75 & 2.56 & 0.19 \\
\hline
\end{tabular}

Table VI. Comparing the results of the pilot study and main study (pre tests)

\begin{tabular}{|c|c|c|c|}
\hline Klopfer's Theme & $\begin{array}{l}\text { Pilot Study } \\
\text { Mean Result }\end{array}$ & $\begin{array}{l}\text { Main Study } \\
\text { Mean Result }\end{array}$ & Difference \\
\hline 1 & 3.52 & 3.46 & 0.06 \\
\hline 2 & 4.16 & 3.71 & 0.45 \\
\hline 3 & 4.02 & 3.91 & 0.11 \\
\hline 4 & 3.52 & 3.31 & 0.21 \\
\hline 5 & 3.18 & 3.36 & $\mathbf{0 . 1 8}$ \\
\hline 6 & 2.39 & 2.18 & 0.21 \\
\hline 7 & 2.54 & 2.30 & 0.24 \\
\hline
\end{tabular}

Table VII. Comparing the results of the pilot study and main study (post tests) 


\section{Figures to be included in the Text}

Figure 1: Choices for Word Card Activity
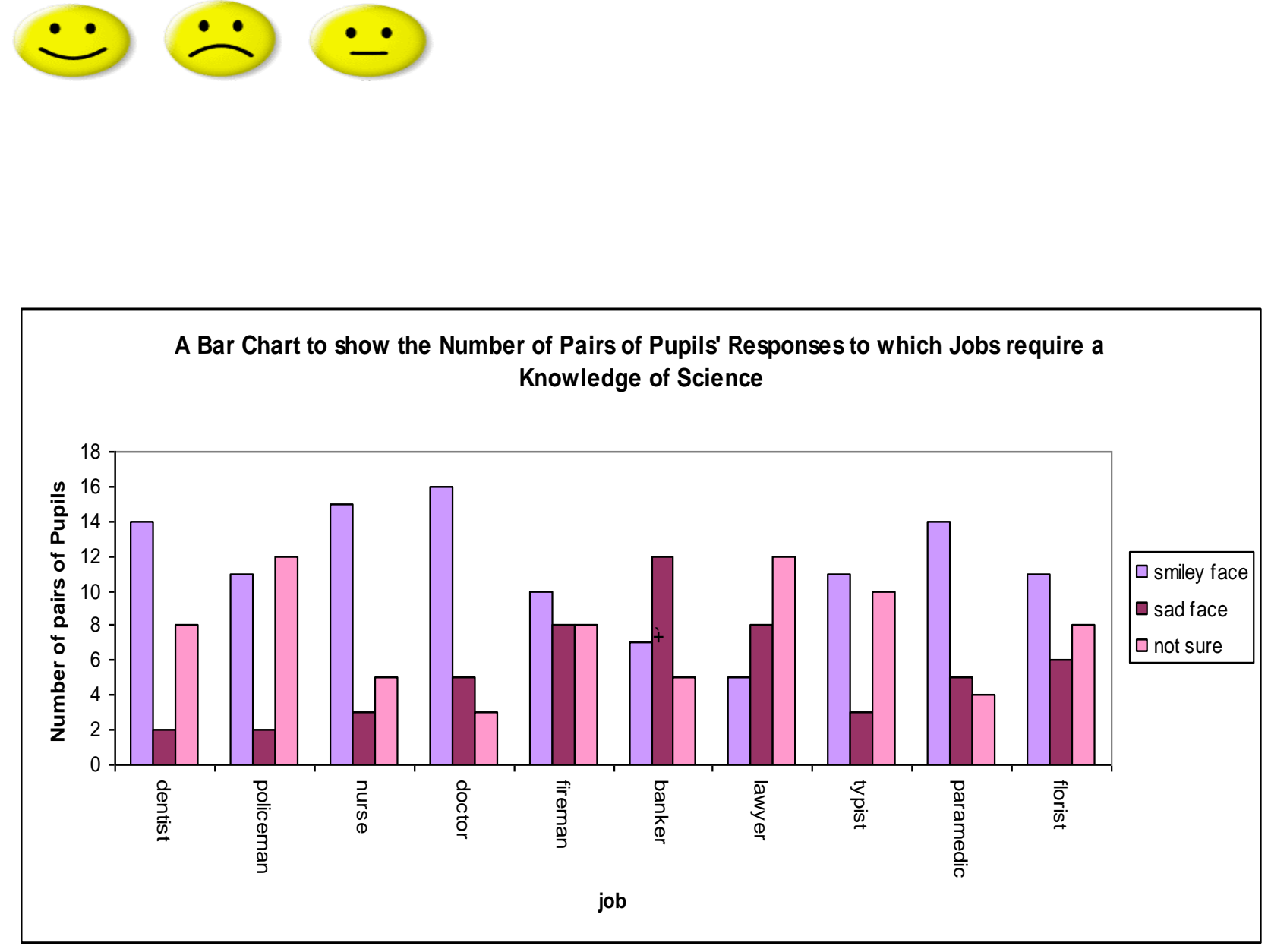

Figure 2. Yr 2 Pupils - Which jobs require some knowledge of science 


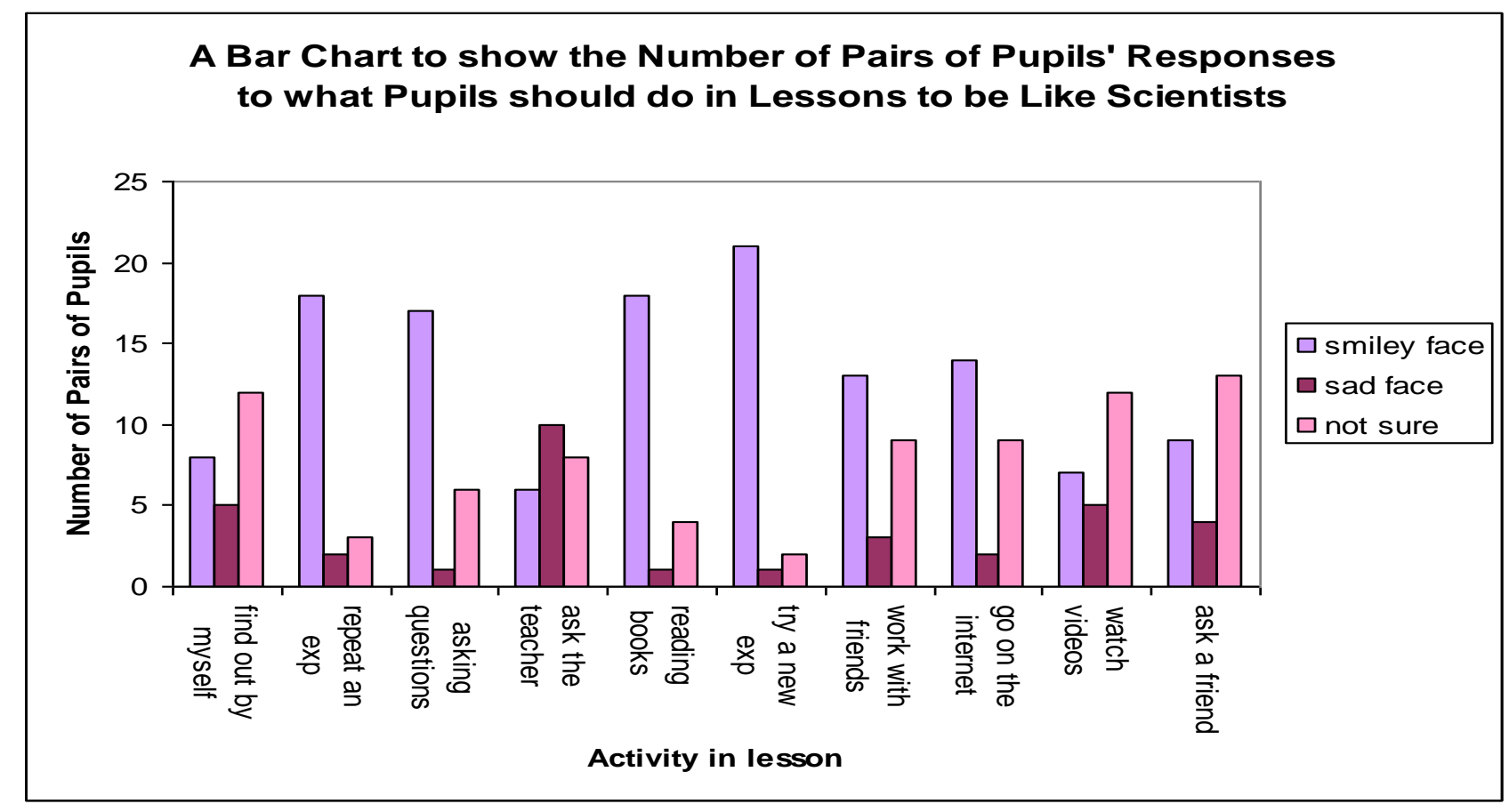

Figure 3. Yr 2 Results - What pupils should do in lessons to be like scientists

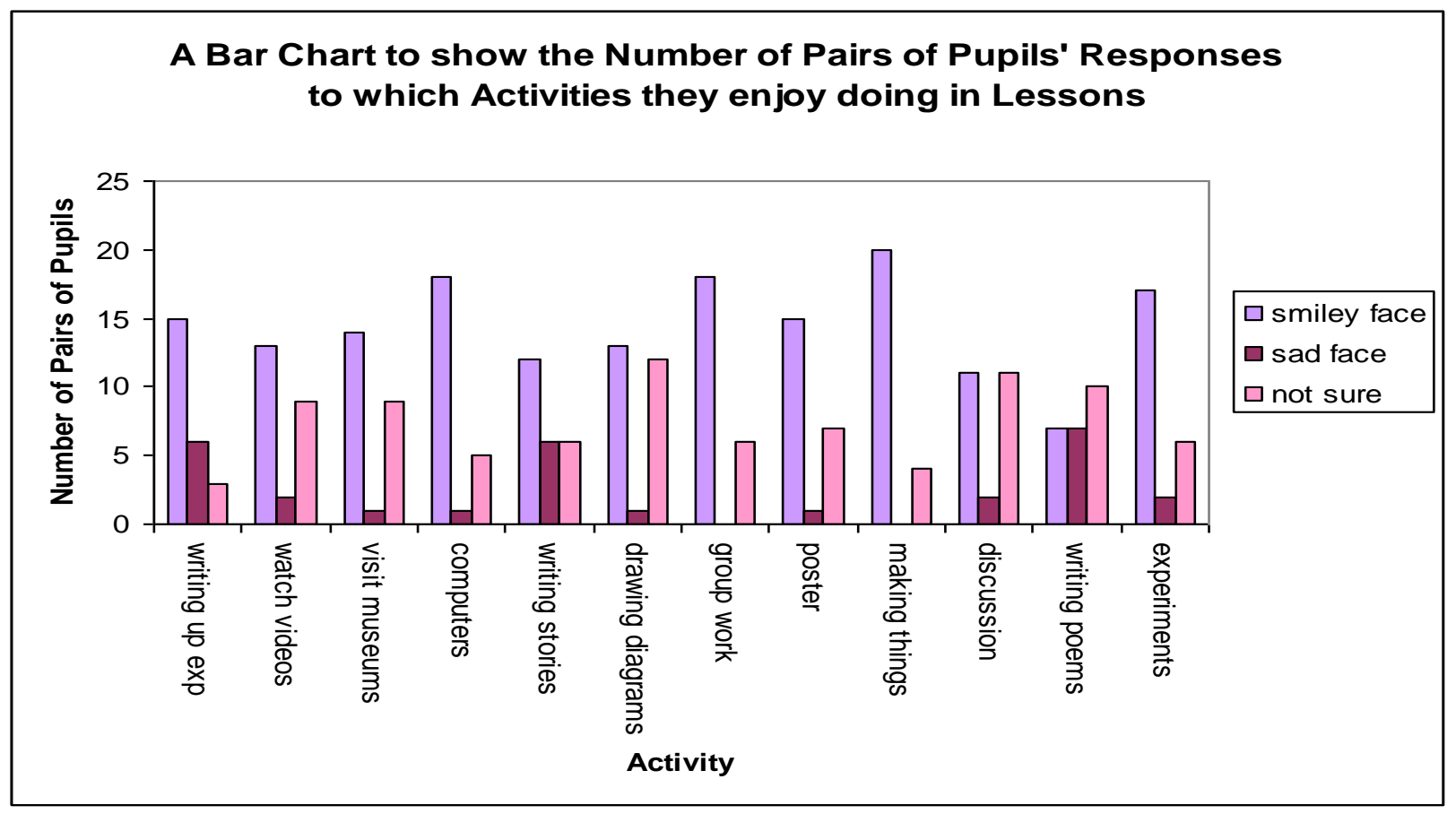

Figure 4. Yr 2 Results - Which activities pupils enjoy in lessons 


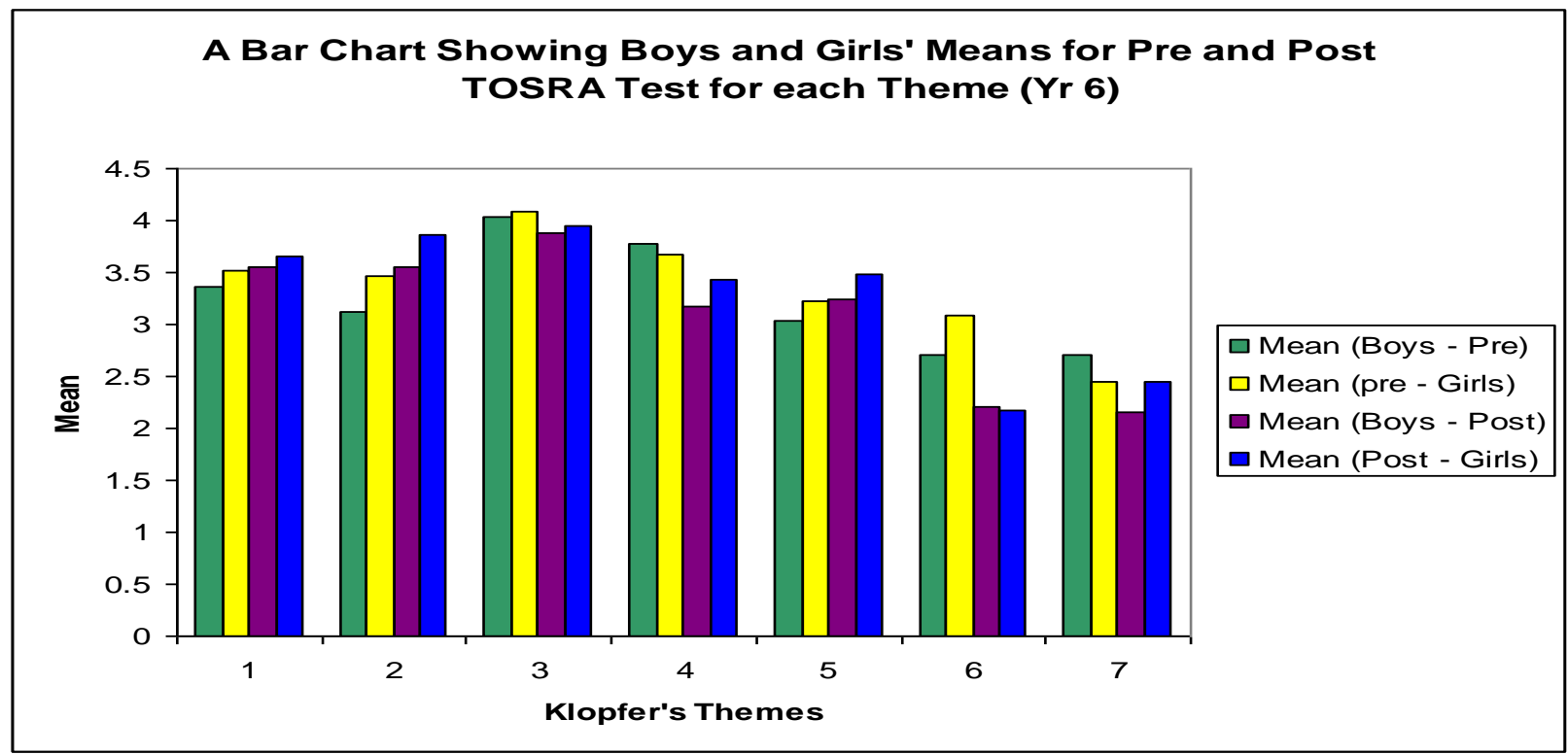

Figure 5. Pre and Post TOSRA test findings for each gender

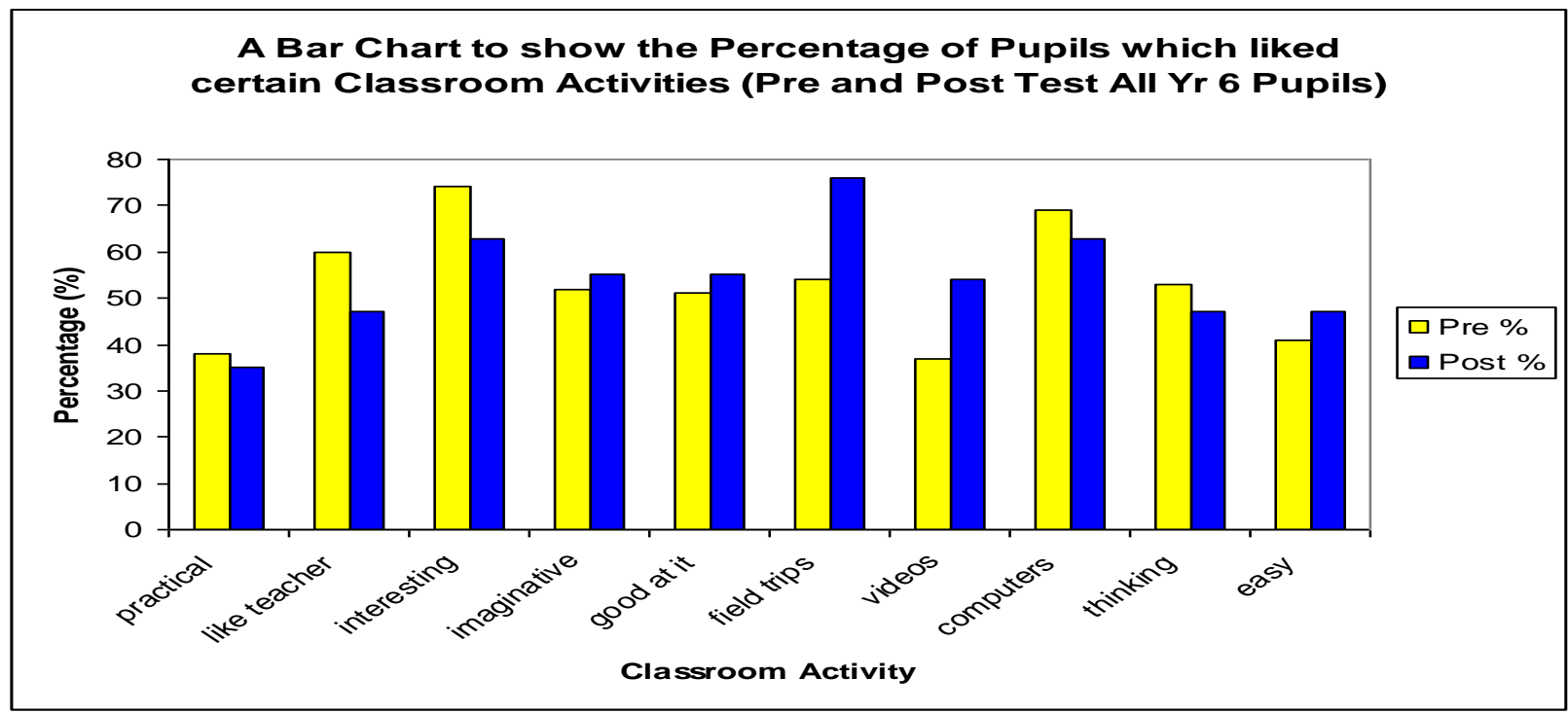

Figure 6: Pre and Post TOSRA test findings for which activities pupils liked in lessons 


\section{Correspondence}

Mrs Sarah Turner

Teacher Education Unit

Matthew Arnold Building

Loughborough University

Leicestershire

LE11 3TU

Tel: 01509222784

Mobile: 07980357681

Email: S.Turner4@lboro.ac.uk

The work was carried out at the above address.

Sarah Turner is a Lecturer in Secondary Science Education at Loughborough University., UK, where her research interests include pupils' attitudes towards science and creative science teaching.

Gren Ireson is a Professor of Science Education at Nottingham Trent University, UK, where his research interests include quantum philosophy, physics of sport and learning and teaching physical sciences. 